\title{
ПРИМУСОВІ ЗАХОДИ МЕДИЧНОГО ХАРАКТЕРУ ЯК НЕВІД'СМНА ЧАСТИНА ПРАВОВОЇ ТА МЕДИЧНӦ̈ РЕФОРМИ У ДЕРЖАВІ
}

\begin{abstract}
КОПАНЧУК Володимир Олександрович - доктор наук 3 державного управління, кандидат юридичних наук, доцент кафедри кримінального права та процесу, Хмельницький університет управління та права імені Леоніда Юзькова ТУРОВЕЦЬ Юрій Миколайович - кандидат юридичних наук, доцент, Заслужений юрист України, доцент кафедри кримінального права та процесу, Хмельницький університет управління та права імені Леоніда Юзькова

ОСМОЛЯН Віталій Анатолійович - кандидат юридичних наук, старший викладач кафедри права, Хмельницький кооперативний торговельно-економічний інститут
\end{abstract}

DOI 10.32782/LAW.UA.2021.2.9

Излагаются правовъе основъ и перспективъ развития уголовного процесса в свете медииинской и правовой реборм в государстве. Рассмотренъ процессуально-правовъие и медииинские вопросъ о возможности законного применения принудительнъгх мер медиичнского характера, а также обоснована необходимость эфбективного сотрудничества работников следственных органов, прокуратуры, суда и медицинских учреждений для качественного и объективного въполнения задач уголовного судопроизводства, и улучшения инновационной политики Украинъ. Сбормированъ и приведенъ предложения по улучшению правовъгх норм действующего уголовного процессуального и медицинского законодательства Украинъл. Раскрьвается значение и место этих новелл в системе права и медицинъ в целом. Сделаннъие въводъ и данъ рекомендации по согласованному применения норм действующего законодательства в практической деятельности врача-психиатра и следователя. Привлечено внимание на необходимость дальнейшего научного сотрудничества ученъх, специилистов в области материального и процессуального права.

Ключевъе слова: уголовнъий процесс, медицина, психиатрия, реборма, инбормация, правоохранительные органъ, досудебное расследование, уголовное производство, экспертиза, врач, специалист.

Постановка проблеми

Примусові заходи медичного характеру є досить специфічною нормою кримінального процесуального законодавства держави, яка постійно розвивається поряд із психіатрією та правовою наукою.

31 квітня 2020 року в Україні розпочався другий етап медичної реформи, який зачепив і психіатричну галузь. Нове фінансування «гроші за пацієнтом», а не традиційна субвенція, не підтримують спеціалізовані клініки, кажуть, що їхній бюджет зменшився в кілька разів. Проте зміни в психіатрії - це не лише про фінансування, а також про монополію, підхід до пацієнтів та їхні права [1].

За словами колишнього міністра охорони здоров'я Максима Степанова: «... до 1 квітня .... ніхто не питав, яка стратегія розвитку психіатричної служби, їх [психіатричні лікарні] ніхто не питав, яким чином вони будуть виживати на тариф, який встановлений, їх ніхто не питав, що робити з 22 тисячами психіатричних хворих із хронічними захворюваннями, які сьогод- 
ні знаходяться в психіатричних лікарнях. Це тяжко хворі наші громадяни, більшість із яких втратили соціальні зв'язки, їх не можна виписувати, не можна просто так закрити лікарні та випустити їх на вулицю»[2].

Саме ця специфічність та унікальність, процеси реформування, які відбуваються у нашій державі, вимагають від судових та правоохоронних органів, медичних працівників розроблення нових позицій та удосконалення вже чинних норм кримінального процесуального законодавства щодо захисту та реалізації прав та свобод осіб із психічними захворюваннями, 3 метою подальшого невід'ємного використання вказаних норм у проведенні ефективного розслідування, у встановленні та притягненні винних осіб до відповідальності.

Це покладає особливу відповідальність на правоохоронні органи щодо проведення якісного та легітимного досудового розслідування у кримінальних провадженнях зазначеної категорії, повного та неупередженого збору доказової бази, що не уявляється можливим без суворого дотримання процедури законності. У цьому і полягає актуальність проблеми.

\section{Аналіз останніх досліджень та публікацій}

Проведений аналіз [1-7] показав, що вчені та практики неодноразово досліджували діяльність правоохоронних органів по збиранні доказової бази, проведенні слідчих дій у цілому та їі окремі аспекти зокрема. Проте розгляд визначальних аспектів щодо застосування примусових заходів медичного характеру вимагає детального дослідження та аналізу.

Мета статті - на підставі проведеного теоретичного аналізу та власного практичного досвіду розглянути визначальні аспекти щодо застосування примусових заходів медичного характеру, а також обгрунтувати необхідність ефективної співпраці працівників слідчих органів, прокуратури, суду та медичних установ для якісного та об'єктивного виконання завдань кримінального провадження та по- кращення інноваційної політики України взагалі.

\section{Виклад основного матеріалу}

Процеси демократизації, які відбуваються у сучасній Україні, посилення охорони прав та законних інтересів українських громадян стосуються всіх галузей нашого життя, усіх напрямків діяльності державних органів. Один з цих напрямків - забезпечення фізичного та психічного здоров'я українського народу. У наш час правовому забезпеченню діяльності медичних та наукових закладів у цій області (наприклад, психіатричній) приділяеться посилена увага.

Разом $з$ тим, психіатрія може опинитися доволі зручним інструментом для уникнення кримінальної відповідальності, а у зв'язку із цим у психіатричних лікарнях можуть опинитися психічно здорові люди, які переховуються від правосуддя.

Чому ж психіатрія може так легко бути використаною для різних порушень законності, для утиску прав окремих громадян або виступити своєрідним шляхом для уникнення кримінальної відповідальності? Спробуємо розібратися у причинах такого положення, щоб уникнути подібні випадки у майбутньому.

На сьогодні у нашій країні та країнах Евросоюзу склалась достатньо розвинута система спеціалізованих закладів, які надають психіатричну допомогу різним верствам населення. Природним наслідком розвитку психіатричної науки, форм та методів діагностики, а також надання медичної допомоги постало значне збільшення кількості виявлених хворих, зміна клініки психічних розладів у бік не різко виражених, легких форм, а також те, що практично головним закладом психіатричної служби, окрім приватних медичних закладів, які надають медичну допомогу психіатричного характеру - лікувальні центри, приватні клініки та інш., постав психоневрологічний диспансер, у якому хворі можуть лікуватися поза стаціонаром. Поєднання диспансерного обслуговування 3 півстаціонарними формами надання психіатричної допомоги (наприклад, ден- 


\section{Кримінальне право, кримінальний процес та криміналістика}

ними стаціонарами) дозволяе не відривати хворих від звичних життевих умов та суттєво не обмежувати їх особисту свободу.

Проте, у зв'язку із цим, роль психіатричних стаціонарів не зменшується. Перевага стаціонарного лікування амбулаторному пояснюється тим, що організаційні основи психіатричної служби в Україні напрацьовувались роками, стали своєрідним надбанням радянського періоду нашої країни, у зв’язку із чим залишились майже такими, як і в минулому столітті.

Тому саме психіатричне лікування в стаціонарних умовах тягне за собою значні обмеження особистої свободи хворих на доволі тривалі терміни.

Використання стаціонарного лікування - може постати одним із «болючих» акцентів психіатрії, який виступить рушійною силою щодо надходження численних скарг на необгрунтованість його застосування судами. Другим «болючим» акцентом може виступити диспансерний психіатричний облік, наприклад, у наслідок суїциїдальних проявів в особистості, сам факт перебування на якому впливає на обсяг та можливість реалізації прав та законних інтересів особи.

Тому правова реформа та медична, які відбуваються у нашій країні, не може не торкатись і цієї галузі життя українського суспільства.

Так, законодавцем внесені та вдосконалені правові норми, які регламентують надання прав та свобод щодо застосування примусових заходів медичного характеру. Тим самим на якісно новий рівень підняте правове регулювання надання такої допомоги.

Зокрема, згідно з частиною 4 статті 503 Кримінального процесуального кодексу України (далі - КПК України) примусові заходи медичного характеру застосовуються лише до осіб, які є суспільно небезпечними [3].

А до основних обставин, що підлягають встановленню під час досудового розслідування у кримінальному провадженні щодо застосування примусових заходів медичного характеру, законодавцем віднесено, серед іншого, i : наявність в особи розладу психічної діяльності в минулому, ступінь i характер розладу психічної діяльності чи психічної хвороби на час вчинення суспільно небезпечного діяння або кримінального правопорушення чи на час досудового розслідування; поведінка особи до вчинення суспільно небезпечного діяння або кримінального правопорушення і після нього та небезпечність особи внаслідок iї психічного стану для самої себе та інших осіб, а також можливість спричинення іншої істотної шкоди такою особою [3].

Таким чином встановлено, що хворі, які представляють за своїм психічним станом безпосередню небезпеку для себе або оточення, можуть бути госпіталізованими без їх згоди, а також без згоди їх родичів або законних представників.

Порядок невідкладної госпіталізації передбачає, що вона здійснюється за рішенням лікаря психіатра 3 обов'язковим негайним повідомленням про це родичів або законних представників хворого $[4,5]$.

Окрім того, законодавець у статті 506 чинного КПК України щодо прав особи, яка бере участь у кримінальному провадженні щодо застосування примусових заходів медичного характеру, теж вказав, що особа, стосовно якої передбачається застосування примусових заходів медичного характеру або вирішувалося питання про їх застосування, користується правами підозрюваного та обвинуваченого в обсязі, який визначається характером розладу психічної діяльності чи психічного захворювання відповідно до висновку судовопсихіатричної експертизи, та здійснює їх через законного представника, захисника. А також наголосив, що у кримінальному провадженні щодо застосування примусових заходів медичного характеру участь захисника є обов'язковою.

Також чинне законодавство, норми моралі та професійної етики диктують, що психіатри та представники правоохоронних органів зобов'язані вживати заходів для охорони прав та законних інтересів осіб, які страждають психічними розладами, та для захисту суспільства від небезпечних дій психічно хворих. 
Зокрема, у нормі статті 513 КПК України встановлено: «Визнавши доведеним, що особа вчинила суспільно небезпечне діяння у стані неосудності або після вчинення кримінального правопорушення захворіла на психічну хворобу, яка виключає можливість застосування покарання, суд постановляє ухвалу про застосування примусових заходів медичного характеру»[3]. А до особи, стосовно якої передбачається застосування примусових заходів медичного характеру або вирішувалося питання про їх застосування, можуть бути застосовані судом наступні запобіжні заходи: передання на піклування опікунам, близьким родичам чи членам сім'ї з обов'язковим лікарським наглядом, або поміщення до закладу з надання психіатричної допомоги в умовах, що виключають їі небезпечну поведінку.

Окрім того, законодавець України зобов'язує правоохоронні органи та прокуратуру контролювати діяльність лікувально-профілактичних закладів охорони здоров'я, які надають психіатричну допомогу (обмежують права і свободи громадян), та розглядати у встановленому порядку заяви та скарги громадян [6]. Таким чином, участь правоохоронних органів, а в деяких випадках навіть і представників громадськості, в інспектуванні лікувально-профілактичних закладів охорони здоров'я, які надають психіатричну допомогу, буде, на наш погляд, сприяти втіленню принципів демократизму та гласності у діяльності медичних закладів цієї спрямованості.

Також дії психіатра можуть бути оскаржені не тільки до його вищого медичного керівництва, проте і до суду. Зокрема, на етапі кримінального провадження ухвала суду про застосування чи відмову в застосуванні примусових заходів медичного характеру, продовження, зміну, припинення застосування примусових заходів медичного характеру або відмова у цьому може бути оскаржена в порядку, передбаченому Законом (частина 1 статті 516 КПК України) [3].

Скарги можуть подавати особи, у відношенні яких вчинені протиправні дії, або їх представники в порядку, визначеному у Законі України «Про звернення громадян»[7].

Таким чином, y чинних нормах Кримінального процесуального кодексу України в певній мірі подолані недоліки відомчих медичних інструкцій, які, на нашу думку, не містять гарантій позавідомчого контролю за правильністю та обгрунтованістю медичних рішень та є такими, що у реаліях сьогодення не передбачають процедури такого контролю.

Тому, на нашу погляд, прокурорський нагляд, медичний відомчий контроль та можливість судового оскарження у поєднанні з допомогою адвоката, у дійсній реалізації на практиці та імплементації у нормотворчій документації визначальних принципів догляду та прав психічно хворих осіб, неминуче будуть покликані обмежити можливість довільних медичних рішень у відношенні окремих осіб, які страждають психічними розладами.

Деякі правознавці-практики та науковці сучасності можуть вказати на малу ефективність і недієвість Глави 39 КПК України. Проте, у ній акумульовано досвід, який накопичений світовою правовою наукою, медициною та людством, а нормативні позиції, які викладені у ній, знайшли відображення у законодавстві багатьох країн, враховують найбільш раціональне та гуманне поводження з особами, які страждають психічними розладами.

У першу чергу, мова йде про систематичний судовий контроль за законністю примусової ізоляції громадянина від суспільства та поетапна процедура останньої, комплексність її продовження.

Так, у статті 509 КПК України законодавцем зазначено, що у разі необхідності здійснення тривалого спостереження та дослідження особи може бути проведена стаціонарна психіатрична експертиза, для чого така особа направляється до відповідного медичного закладу на строк не більше двох місяців. Питання про направлення особи до медичного закладу для проведення психіатричної експертизи вирішується під час досудового розслідування - ухвалою слідчого судді за клопотан- 


\section{Кримінальне право, кримінальний процес та криміналістика}

ням сторони кримінального провадження в порядку, передбаченому для подання та розгляду клопотань щодо обрання запобіжного заходу, під час судового провадження - ухвалою суду. А в частині 3 статті 514 цього ж Кодексу конкретизовано та зазначено, що розгляд питання про продовження, зміну чи припинення застосування судом примусових заходів медичного характеру здійснюється за письмовою заявою представника закладу з надання психіатричної допомоги (лікаря-психіатра), де тримається ця особа. До заяви додається висновок комісії лікарів-психіатрів, що обгрунтовує необхідність продовження, зміни або припинення застосування таких примусових заходів. Розгляд питання про зміну чи припинення застосування судом примусових заходів медичного характеру може також здійснюватися за письмовою заявою особи, до якої застосовуються примусові заходи медичного характеру, або їі захисника чи законного представника у разі, якщо така особа за своїм станом здоров'я не може усвідомлювати свої дії (бездіяльність) чи керувати ними, в тому числі не може усвідомлено подати до суду відповідну заяву. До заяви додається висновок комісії лікарів-психіатрів закладу, у якому особі надається психіатрична допомога, або, у разі наявності, висновок обраного особою незалежного лікаря-психіатра.

Таким чином, судовий розгляд 3 його гласністю та змагальністю, колегіальністю та незалежністю створює демократичні умови для прийняття обгрунтованого рішення, а також для постійного контролю за станом справ у психіатричних лікарнях.

У зв'язку із вищевикладеним, вважаємо за доцільне уповноважити прокуратуру або утворити керівну посаду «Головний лікар-психіатр» у закладах охорони здоров'я, який буде наділений вагомими повноваженнями, а саме: він буде не лише вирішувати долю осіб, які потрапили у сферу діяльності психіатрії, але і розглядати та вирішувати скарги та звернення на дії медичних психіатричних закладів у комплексі. Окрім того, на нього можна буде покласти ряд інших обов'язків та на- дати певні права та повноваження у галузі медицини та охорони здоров'я. Проте, разом із тим, необхідно розуміти, що зосередження такої влади в руках однієї людини може виявитись для неї занадто важким тягарем та згубним для усієї справи, призвести до помилок та зловживань або лише до формального виконання своїх обов'язків.

У правовій державі, одним з основних принципів якої повинно бути верховенство права та закону, при наданні громадянам психіатричної допомоги пріоритет повинен надаватись не адміністративниммедичним методам контролю, а правовим: юридичні заклади повинні спостерігати за тим, щоб не порушувались права людини на свободу, гідність та недоторканність особистості.

На жаль, ні в чинному КПК України, ні в Законі України «Про прокуратуру» чітко та детально не визначені обов'язки прокурора по здійсненню нагляду за діяльністю психіатричної служби; не деталізовані права адвоката, не зазначені порядок та умови його спілкування з психічно хворою особою, а можливість оскаржити дії лікаря-психіатра до суду далеко не завжди виявляється реальним для психічного хворої особи, яка перебуває в ізоляції від суспільства.

Тому вважаємо за доцільне спільно юристам та медичним працівникам розробити та доповнити чинні норми кримінального процесуального законодавства України рядом правових позицій-новел, які, на наш погляд, своїм змістом будуть нести важливі рекомендації загального характеру, вказувати на конкретні положення, дотримання яких буде гарантувати права особистості та реалізацію її законних інтересів, а саме:

- заборонити під будь-яким приводом превентивну ізоляцію хворого;

- ввести у якості безумовного правила позицію про те, що ліки видаються хворому тільки для лікування та їх заборонено використовувати для «покарання» хворих або для «зручності» лікарського персоналу; 
- чітко визначити та деталізувати у всіх закладах MO3 України однакові за змістом та об’ємом права хворого, якими він користується, перебуваючи у психіатричній лікарні (закладі);

- регламентувати та прописати у ряді норм чинного законодавства України функції адвоката, який представляє інтереси психічно хворої особи;

- закріпити невід'ємне право психічно хворої особи на періодичне звернення до керівництва медичного закладу 3 клопотанням про виписку.

Як висновок до статті зазначимо, що, на нашу думку, примусові заходи медичного характеру $є$ досить специфічною нормою кримінального процесуального законодавства держави, яка постійно розвивається поряд із психіатрією та правовою наукою. Саме ця специфічність та унікальність, процеси реформування, які відбуваються у нашій державі, вимагають від судових та правоохоронних органів, медичних працівників розроблення нових позицій та удосконалення вже чинних норм кримінального процесуального законодавства щодо захисту та реалізації прав та свобод осіб із психічними захворюваннями, 3 метою подальшого невід'ємного використання вказаних норм у проведенні ефективного розслідування, у встановленні та притягненні винних осіб до відповідальності.

Зважаючи на наявність недоліків у цій сфері процесуально-правової та медичної діяльності, вважаємо за актуальні подальші дослідження відповідної спрямованості, адже останні створюватимуть перспективи теоретичних та практичних напрацювань та сприятимуть розв'язанню проблемних питань у цьому напрямку.

\section{Мiтература}

1. Модіна O., Медреформа в психіатрії: все, про що ви не знали / Радіо Свобода [Електронний ресурс] : www.radiosvoboda. org (дата звернення: 15.06.2021).

2. Степанов M., [Виступ] Брифінг MO3 України від 28.04.2020 / Укрінформ
[Електронний ресурс] : www.ukrinform.ua (дата звернення: 05.06.2021).

3. Кримінальний процесуальний кодекс України. Закон України від 13 квітня 2012 року №4651-VI (редакція станом на 15.06.2021) [Електронний ресурс] : http://zakon.rada.gov.ua (дата звернення: 05.06.2021).

4. Наказ МОЗ України «Про затвердження форм первинної облікової документації та інструкцій щодо їх заповнення, що використовуються у закладах охорони здоров' я незалежно від форми власності та підпорядкування» від 14 лютого 2012 року № 110 (редакція станом на 05.06.2021) [Електронний ресурс] : http:// search. ligazakon.ua (дата звернення: 05.06.2021).

5. Мішиев В.Д., Омелянович В.Ю., Гриневич С.Г. Психіатрія. Еталони практичних навичок. Електронний навчальний посібник.- Київ, 2018. [Електронний pecypc] : http:// nmapo.edu.ua (дата звернення: 05.06.2021).

6. Закону України «Про прокуратуру» iз змінами, внесеними зігдно із Законом від 27 квітня 2021 року № 1414 - IX (редакція станом на 15.06.2021) [Електронний pecypc] : http://zakon.rada.gov.ua (дата звернення: 05.06.2021).

7. Закону України «Про звернення громадян» від 2 жовтня 1996 року№ 653 - XIV (редакція станом на 15.06.2021) [Електронний ресурс] : http://zakon.rada. gov.ua (дата звернення: 05.06.2021).

Kopanchuk V.A., Turovets $\mathrm{Yu} . \mathrm{N}$.,

Osmolian V.A.

COMPULSORY MEASURES OF A MEDICAL NATURE AS AN INTEGRAL PART OF LEGAL AND MEDICAL REFORM IN THE STATE

The article contains the legal basis and prospects for the development of the criminal process in the light of medical and legal reforms in the state are stated. The authors considered the procedural, legal and medical issues about the possibility of the lawful application of compulsory medical measures, and also substantiated the need for effec- 


\section{Кримінальне право, кримінальний процес та криміналістика}

\section{АНОТАЦІЯ}

Викладаються правові основи та перспективи розвитку кримінального процесу у світлі медичної та правової реборм у державі. Розглянуто прочесуально-правові та медичні питання щодо можливості законного застосування примусових заходів медичного характеру, а також обгрунтована необхідність ебективної співпрачі прачівників слідчих органів, прокуратури, суду та медичних установ для якісного та об'єктивного виконання завдань кримінального провадження та покращення інновачійної політики України. Сбормовані та наведені пропозищій щодо покращення правових норм чинного кримінального прочесуального та медичного законодавства Украӥни. Розкривається значення та місце изих новел у системі права та медицини у иілому. Зроблені висновки та надані рекомендащї щодо узгодженого застосування норм діючого законодавства у практичній діяльності лікаря-психіатра та слідчого. Привернуто увагу на необхідність подальшої наукової співпрачі вчених, спечіалістів у галузі матеріального та процесуального правa.

Ключові слова: кримінальний прочес, медицина, психіатрія, рефборма, інформачія, правоохоронні органи, досудове розслідування, кримінальне провадження, експертиза, лікар, спеціаліст. tive cooperation of employees of investigative bodies, prosecutors, courts and medical institutions for the qualitative and objective implementation of the tasks of criminal proceedings and improving the innovation policy of Ukraine. Formed and presented proposals for improving the legal norms of the current criminal procedural and medical legislation of Ukraine. The meaning and place of these short stories in the system of law and medicine in general are revealed. The conclusions were drawn and recommendations were given on the coordinated application of the norms of the current legislation in the practice of a psychiatrist and an investigator. Attention is drawn to the need for further scientific cooperation of scientists, specialists in the field of substantive and procedural law.

Keywords: criminal procedure, medicine, psychiatry, reform, information, law enforcement agencies, pre-trial investigation, criminal proceedings, expertise, doctor, specialist. 